\title{
Dysplastic nevus
}

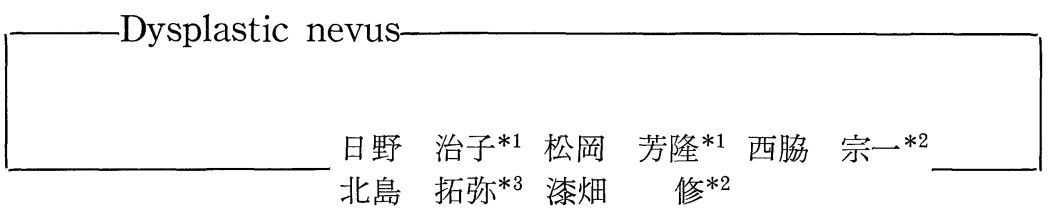

\section{Summary}

当院 22 年間で切除した母斑ないし小色素斑 438 個を臨床像と組織像で検討 した結果, Elder ら特よび NIH の設けた定義に相当する dysplastic nevus は 4 個あった。これらの 組織所見では, 表皮真皮境界部に melanocyte の胞巣形成が顕著であった。悪性黒色腫の 前駆症状といわれる dysplastic nevus であるが，これを臨床形態のみで診断がつくか試 みたが，困難であった。

\section{緒}

\section{言}

われわれの日常診療中，色調の濃淡があり， 黒色調が強く, 周囲にいわゆる浸み出しさえ伴 ら母斑にしばしば遭遇し，悪性黒色腫との鑑別 を必要とすることがある。しかも，生検をする と, その組織像では, 顕著な境界部活性 (junctional activity) を呈し，母斑細胞も紡錘形の ものがみられますすす診断が困難となる。

最近, dysplastic nevus の概念がとりいれら れ，組織抒よび臨床に関して種々の報告がされ ている。通常, dysplastic nevus は, Dysplastic nevus syndrome または B-K mole syndrome とよばれる家族性皮虐悪性黒色腫にみられるも ので, 悪性黒色腫の前駆状態の母斑とされてい る112)。Dysplastic nevus syndrome 括よび家族

*1 Haruko HINO, Yoshitaka MATSUOKA: 関東中央病院皮膚科

*2 Munekazu NISHIWAKI, Osamu URUSHI-

BATA：東邦大学大橋病院皮膚科

*3 Takuya KITAJIMA：都立府中病院皮膚科
内に同症を認めない sporadic type の症例 ${ }^{334)}$ にみられるもののみを dysplastic nevus という べさか，注かに何の皮膚病変をもたない 1 個体 にみられた 1 個の母斑でも臨床と組織がそれに 相当するならば dysplastic nevus とよんでよい かが問題となる。この点について， Elder らは dysplastic nevus の臨床と組織学的診断基準を 提示したが5)，1983年, Consensus development conference of precursors to malignant melanoma (National Institutes of Health in U.S.A.) で は，家系内に同症をみる場合を dysplastic nevus syndrome とし，家系内発生のない sporadic case にみられるものを dysplastic nevi とし $た^{6)}$ 。

われわれは, これらの診断基準576)をもとに， われわれの経験した症例を検討した。

\section{症 例}

1) 統 計

昭和 38 年 6 月より, 昭和 60 年 5 月末すでの 22 年間に 380 人から，のべ438個の母斑ないし色素 斑を切除し，病理標本を作製した。これらを臨 
床的形態と組織像により分類すると表 1 のごと くとなる。すなわち，真皮母斑172個(39.3\%), 複合母斑188個（42.9\%), 境界母斑78個（17.8 \%), 臨床形態としては, 隆起したもの 278 個 (63.5\%), 扁平ないし浸潤を触れても隆起のな いもの 158 個 (36.1\%) であった。

複合母斑で, しかも比較的扁平なるのは58個 (13.2\%) であったが, Elder ら の dysplastic nevus の臨床的定義に相当する母 斑が14個（3.2\%）みつかった（表 2)。この14 個のらち 3 個は 1 症例でみられたものである が，他の11個はすべて単発例である。さらに, これら14個に対し, 組織学的定義をあわせて検

表 1. 検索した母沙

\begin{tabular}{|c|c|c|c|c|c|}
\hline 臨床 & & 扁 平 & 型 & & \\
\hline 組織 & 隆起型 & $\begin{array}{l}\text { 色素性 } \\
\text { 玟 }\end{array}$ & $\begin{array}{l}\text { 点状集 } \\
\text { 集性 }\end{array}$ & $\begin{array}{l}\text { 色 } \\
\text { 素 } \\
\text { 性斑 }\end{array}$ & 計 \\
\hline $\begin{array}{l}\text { 真皮(内) } \\
\text { 母: 斑 }\end{array}$ & 161 & 3 & 8 & & 172 \\
\hline 複合母斑 & 115 & 58 & 13 & 2 & 188 \\
\hline 境界母:斑 & 2 & 74 & 2 & & 78 \\
\hline 計 & 278 & 135 & 23 & 2 & 438 \\
\hline
\end{tabular}

討すると，4個 (0.9\%) が, 臨床像扣よび組 織像ともにいわゆる dysplastic nevus といらべ き所見を呈していた。

\section{2) 症例}

症例 $2: 23$ 歳, 女

既往歴：特記すべきことはない。

家族歴: 家系内に悪性黒色腫の発症はなく, 色素斑がとくに多い者もいない。

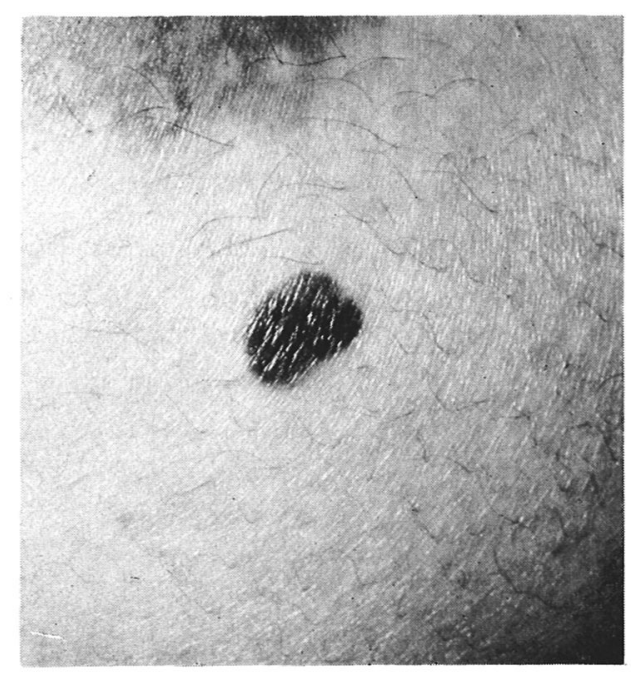

図 1. 症例 2, 左乳房左下方外方の赤褐色斑

表 2. 臨床像または組織像が dysplastic nevus の定義に相当する丹斑

\begin{tabular}{|c|c|c|c|c|c|c|c|c|c|c|c|c|}
\hline \multirow[b]{2}{*}{ 症例 } & \multirow[b]{2}{*}{ 年齢 } & \multirow[b]{2}{*}{ 性 } & \multirow[b]{2}{*}{ 母斑 } & \multirow[b]{2}{*}{ 部 位 } & \multirow[b]{2}{*}{ 発生時期 } & \multirow[b]{2}{*}{ 大きさ } & \multirow[b]{2}{*}{ 色 調 } & \multicolumn{5}{|c|}{ 組 織 像 } \\
\hline & & & & & & & & 母:斑の分類 & $\begin{array}{l}\text { mela- } \\
\text { nocyte } \\
\text { 胞巣形 } \\
\text { 成 }\end{array}$ & $\begin{array}{l}\text { mela- } \\
\text { nocyte } \\
\text { dys- } \\
\text { plasia }\end{array}$ & $\begin{array}{l}\text { 真皮乳 } \\
\text { 頭層の } \\
\text { fibro- } \\
\text { plasia }\end{array}$ & $\begin{array}{l}\text { 真皮炎 } \\
\text { 症性細 } \\
\text { 胞浸潤 }\end{array}$ \\
\hline 1 & 50 & 女 & 1 & 右腹 & 10年前 & 爪甲大 & 黒色 & compound & H & - & - & - \\
\hline 2 & 23 & 女 & 2 & 左乳房左外下 & 不明 & 大豆大 & 赤褐色 & compound & H & H & H & H \\
\hline \multirow[t]{2}{*}{3} & 3 & 女 & 3 & 左膝膕 & 生下時 & 沜卵大 & 黒色 & compound & H & - & - & - \\
\hline & & & 4 & 背部 & 不明 & 小豆大 & 黒褐色 & compound & H & W & H & + \\
\hline \multirow[t]{2}{*}{4} & 44 & 男 & 5 & 背部 & 不明 & 小豆大 & 褐色 & compound & + & - & - & - \\
\hline & & & 6 & 背部 & 不明 & 小豆大 & 黒褐色 & compound & H & + & + & + \\
\hline 5 & 17 & 女 & 7 & 右牌部 & 2 年前 & 大豆大 & 黒褐色 & compound & H & - & - & + \\
\hline 6 & 39 & 女 & 8 & 背部 & 不明 & 小豆大 & 黒褐色 & compound & + & - & - & + \\
\hline 7 & 25 & 女 & 9 & 左第 3 指指背 & 1 年前 & 小豆大 & 黒褐色 & compound & H & H & W & + \\
\hline 8 & 7 & 女 & 10 & 心窩部 & 1 年前 & 大豆大 & 黒色 & compound & H & - & - & - \\
\hline 9 & 50 & 女 & 11 & 右大腿 & 子供の頃 & 卵黄大 & 黒褐色 & compound & + & - & - & - \\
\hline 10 & 66 & 男 & 12 & 右膝䐃 & 青年期 & 大豆大 & 黒褐色 & compound & + & - & - & - \\
\hline 11 & 53 & 女 & 13 & 左大腿 & 不明 & 大豆大 & 黒褐色 & compound & H & - & - & - \\
\hline 12 & 27 & 男 & 14 & 右上腹部 & 不明 & 大豆大 & 黒褐色 & compound & H & - & - & + \\
\hline
\end{tabular}




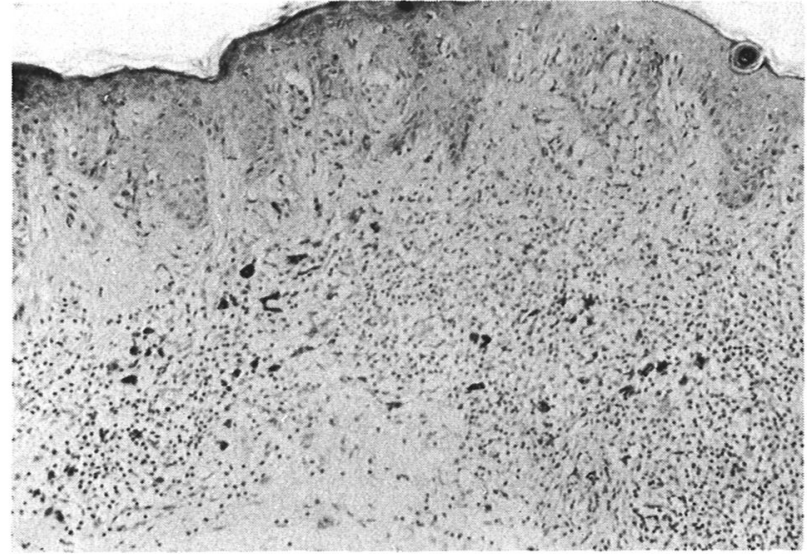

図 2. 表皮突起の不規則な延長, 真皮の炎症性細胞浸潤が顕 著である。

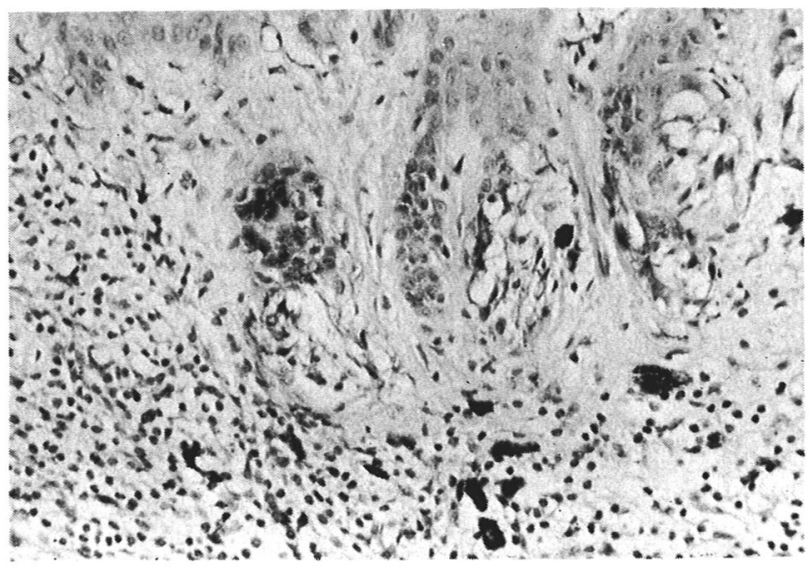

図 3. 表皮真皮境界部の melanocyte の胞采形成。乳頭層の fibroplasia

現病歴：いつごろからあったか不明だが，左 乳房の小色素斑が，最近徐々に拡大してきたた め来院

現 症：左乳房左下外側に, 大豆大, 扁平, 赤褐色の小色素斑が 1 個又られた。他の部位に とくに目立つ色素斑はない（図１）。

組織像 : 表皮突起の不規則な延長がみられ， 表皮真皮境界部には melanocyte の胞巣形成が 顕著である。胞巣内の melanocyte は, 紡錘形 で, 水平に走行している。乳頭層には, lamellar な結合織の fibroplasia も認められる。真皮上 層には，帯状に，リンパ球を主体とする炎症性 細胞浸潤が非常に顕著である（図 2，3）。

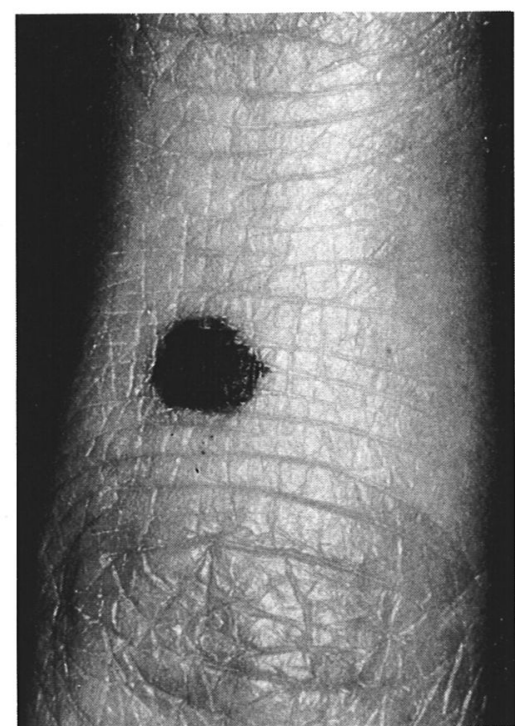

図 4. 症例 7, 左第 3 指指背の黒褐色斑
症例 7:25歳，女

既往歴：特記すべきことはない。

家既歴 : 家系内に悪性黒色腫の発症や，色素 斑の多発する者はいない。

現病歴 : 約 1 年前，左第 3 指指背の黒色斑に 気づいた。それ以前にはまったく何も認めなか った。次第に拡大してきたため来院

現 症：左第 3 指指背中央に小豆大, 扁平, 黒褐色，辺縁は不規則で周囲へ向かってわずか に褐色の浸又出しを伴ら小色素斑が 1 個みられ た。所属リンパ節は触知しない。他の部位に, いわゆるホクロで目立つものはなかった（図 4 )。 


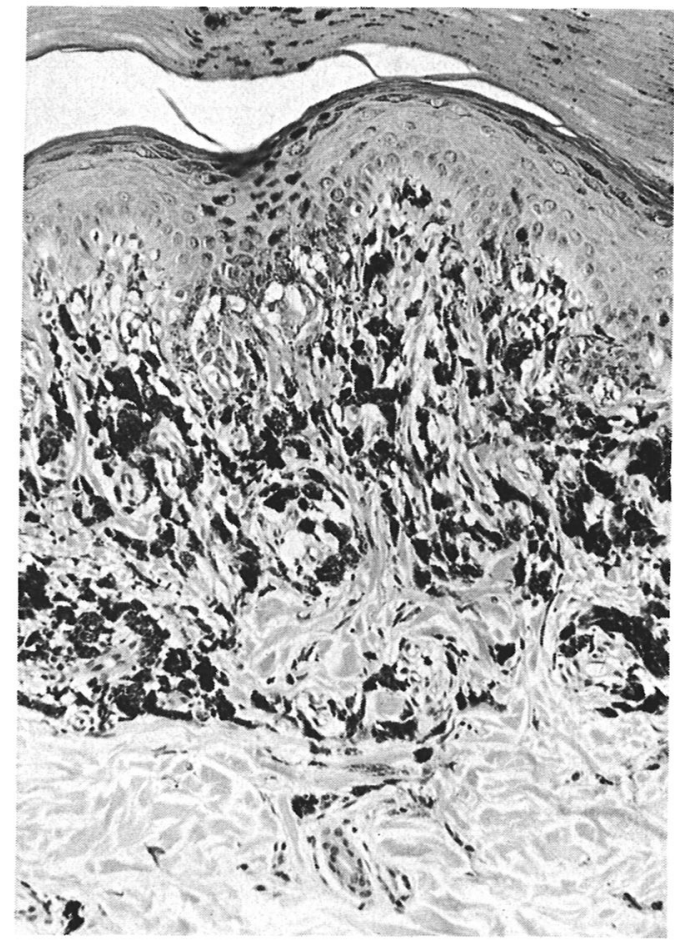

図 5. 境界部活性の強い母斑。腫瘍細胞内には melanin が非常に多い。

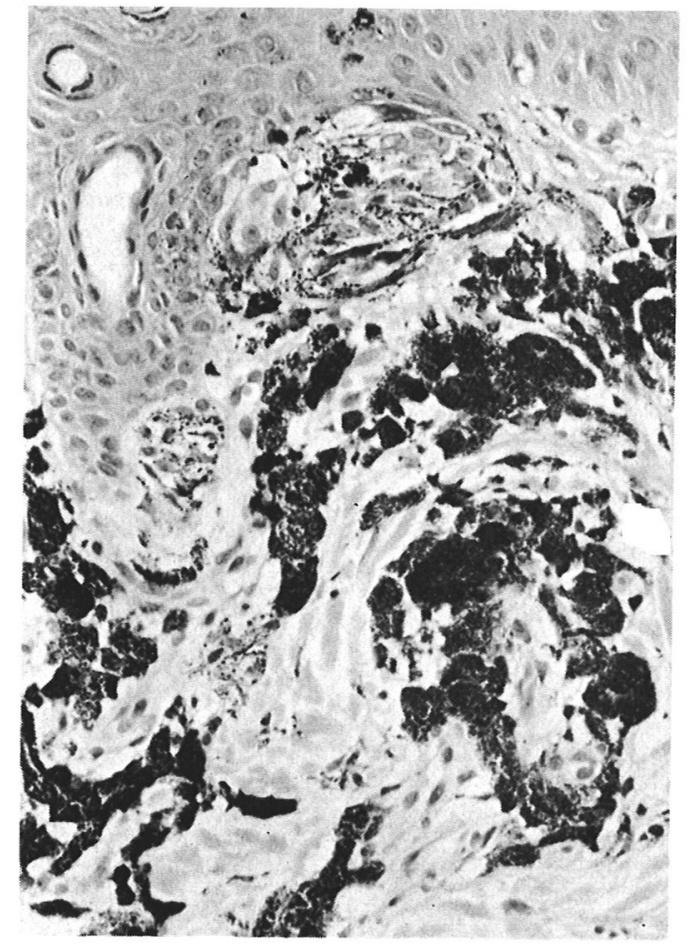

図 6. 表皮真皮境界部に, melanocyte の胞巣形 成がみられる。

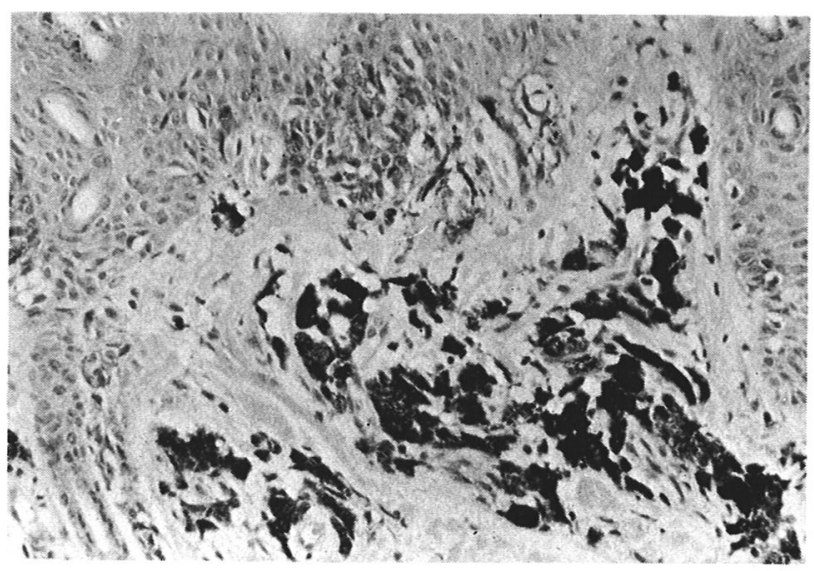

図 7 .

真皮乳頭層の結合織の fibroplasia

組織像：全体的には compound type の母斑 細胞母斑の像を呈しているが，表皮真皮境界部 には melanocyte の胞巣形成が著明である（図 5 )。胞巣内細胞は紡鍾形で, 表皮と水平飞走 行し, 異形成もみられる。胞体は明るく豊富 で, 微細な melanin 顆粒が多量に認められる。 巨大 melanin 顆粒をもつものもある(図 6 )。 真皮の母斑細胞内には多量の melanin 顆粒が
みられる。真皮乳頭層には, 結合織が lamellar に走行する fibroplasia も明瞭である（図 7)。

\section{考察}

Clark らが，多数の色素性母斑と悪性黒色腫 の家族内発生例を報告して以来 ${ }^{2}$, この母斑は 墨性黒色腫の前駆症状として注目されてきてい 
る。このような家族例は familial type といわれ る。一方, 個体に多数の母斑があっても, 家族 内発生をみない場合は sporadic type といわれ ている。また, NIH consensus ${ }^{6)}$ とり, familial type を dysplastic nevus syndrome (DNS) と よび, sporadic type を dysplastic nevi (DN) とよんでいる。さらに，各個人に 1 〜数個の母 斑があるのみで，家族内発生はもちろんその個 人に他の目立つ色素斑さ光ない症例の母斑を dysplastic nevus と称している。

DNS, DN, dysplastic nevus のいずれも, そ れらが悪性黒色腫の前駆症状となりらる可能性 を秘めているといわれる性質上，その定義と診 断が問題となる。臨床的にも，ときに悪性黒色 腫が疑わしいような場合があり，治療的必要性 をも考慮し，その臨床像のみで診断をつけらる か否かを試みた。われわれの検討した 438 個の

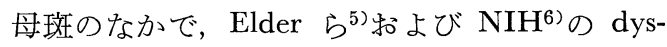
plastic nevus の臨床像としての定義に相当する ものは14個めった。しかし, 組織学的所見もあ わせて検討した場合は，4個が相当した。すで にいわれているように8) 11), dysplastic nevus の診断には組織所見が不可欠であり, 臨床像の みでは, 診断はつけ難かった。

Dysplastic nevus が将来悪性黒色腫に変化す るか否かは，いまだ解決されていない。DNS 扣よび DN では，多数の母斑の経過を注意深 く観察することにより，その変化をみることが できるかもしれない。また，実際，悪性黒色腫 の発生の報告もみられる ${ }^{1) 4)}$ 。しかし，1～数 個のみの dysplastic nevus の場合, その変化に ついては，いまだ不明な点が多い。

438 個の母斑群のうち 4 個，すなわち約 $1 \%$ の, 通常の母斑細胞母斑より色調が濃く, 特徵 のある臨床像と, 胞巣形成傾向が強く, 炎症性 細胞浸潤, fibroplasia などの特徵ある組織像を
もつ母斑に dysplastic nevus の名をつけること は，他の母斑細胞母斑と区別する意味に扔いて 必要と考光る。

\section{文献}

1) Anderson, D.E., Smith, J.L. Jr. \& McBride, C.M.: Hereditary aspects of malignant melanoma. J. Amer Med. Assoc., 200: 741-746, 1967.

2) Clark, W.H. Jr., Reimer, R.R., Greene, M., Ainsworth, A.M. \& Mastrangelo, M.J.: Origin of familial malignant melanomas from heritable melanocytic lesions. Arch. Dermatol., 114: 732-738, 1978.

3) Rahbari, H \& Mehregan, A.H.: Sporadic atypical mole syndrome. Arch. Dermatol., 117: 329-331, 1981.

4) Elder, D.E., Goldman, L.I., Goldman, S.C., Green, M.H. \& Clark, W.H. Jr.: Dysplastic nevus syndrome. Cancer, 46: 1787-1794, 1980.

5) Elder, D.E., Kraemer, K.H., Green, M.H., Clark, W.H. Jr., \& Guerry, D.P.: The dysplastic nevus syndrome. Amer J. Dermatopathol., 4: 455-460, 1982.

6) National Institutes of Health consensus development conference summary, Vol. 4, No. 9, 1983.

7）高橋 博之, 堀越貴志, 神保 孝一：dyspalstic nevus の臨床, 組織学的及び超微構造的特異性 と悪性黒色腫との関連. 1. 臨床及び 組織像. 日皮会誌，94：1537-1546，1984.

8) 三原一郎：Dysplastic nevus，皮膚臨床，27： 841-849, 1985.

9）長谷川正次，川部美智子，宇田川晃，宇野明 彦, 中林康青, 堀 嘉昭: Dysplastic nevus の 1 例. 皮膚臨床, 27：851-854， 1985.

10) 斎田俊明, 川村美保子, 堀 嘉昭: Dysplastic nevus syndrome (Sporadic type), 皮膚臨床, 27: 855-860, 1985.

11）中川秀己, 今門純久, 久木田淳 : Dysplastic nevus の 3 例. 皮膚臨床, 27：861-866, 1985. 